\title{
The geochronological potential of isoleucine epimerisation in cassowary and megapode eggshells from archaeological sites
}

\author{
Simon J. Clarke ${ }^{\mathrm{a}, *}$, Gifford H. Miller ${ }^{\mathrm{b}}$, Colin V. Murray-Wallace ${ }^{\mathrm{a}}$, \\ Bruno David ${ }^{\mathrm{c}}$, Juliette M. Pasveer ${ }^{\mathrm{d}}$

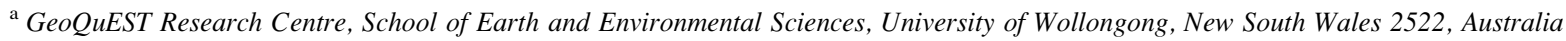 \\ ${ }^{\mathrm{b}}$ Institute of Arctic and Alpine Research, and Department of Geological Sciences, University of Colorado, Boulder, CO 80309-0450, USA \\ ${ }^{\mathrm{c}}$ Programme for Australian Indigenous Archaeology, School of Geography and Environmental Science, \\ Monash University, Clayton, Victoria 3800, Australia \\ ${ }^{\mathrm{d}}$ Department of Archaeology and Natural History, Research School of Pacific and Asian Studies, \\ The Australian National University, Canberra, ACT 0200, Australia
}

Received 24 March 2005; received in revised form 18 August 2006; accepted 27 September 2006

\begin{abstract}
Our research demonstrates that the extent of isoleucine epimerisation $(A / I)$ in fragments of avian eggshells provides geochronological information in archaeological contexts. In the archaeological sequence of Hay Cave, northern Queensland, Australia, there is an excellent correspondence between the $A / I$ values of Australian brush-turkey (Alectura lathami) eggshells $(n=99)$ and independent geochronological control ( $n=16$ radiocarbon ages including 4 on eggshell calcite). The $A / I$ values identify three phases of deposition during the Holocene at Hay Cave. In contrast to the Alectura eggshell A/I values, a poor correspondence was observed between the A/I values of cassowary (Casuarius) eggshells from Toé $(n=35)$ and Kria caves $(n=23)$ (Ayamaru Plateau, Papua) and the depths from which the specimens were recovered in these stratified sequences. Given coherent archaeofauna trends and radiocarbon chronologies $(n=8$ and 2 eggshell calcite radiocarbon ages at Toé and Kria, respectively) with respect to depth, the variable $A / I$ values are not explicable in terms of mixing. Rather, the variability is most likely due to exposure of the eggshells to the high temperatures of campfires. Despite the variability, eggshells with relatively low A/I values amongst specimens recovered from similar depths (and therefore presumably least influenced by high temperatures) exhibit a gradual increase in $A / I$ with respect to depth, as expected in a stratified deposit. From this observation it is suggested that the identification of heated eggshells will increase confidence in geochronological information provided by $A / I$. These studies illustrate the complications that arise from campfire-induced acceleration of amino acid racemisation and emphasise that although this phenomenon is common, it is not universally encountered in archaeological contexts.
\end{abstract}

(C) 2006 Elsevier Ltd. All rights reserved.

Keywords: Isoleucine; Epimerisation; Eggshell; Amino acid; Geochronology

\section{Introduction}

The diagenetic reaction, isoleucine epimerisation (analogous to amino acid racemisation), is commonly used as a proxy for geological time in amino acid-bearing fossils such as mollusc shells and fragments of avian eggshells (e.g., Wehmiller

\footnotetext{
* Corresponding author. Present address: Charles Sturt University, PO Box U314, Wagga Wagga, New South Wales 2678, Australia.

E-mail address: siclarke@csu.edu.au (S.J. Clarke).
}

et al., 1995; Miller et al., 1999b). Isoleucine epimerisation is the interconversion of the epimers L-isoleucine $(I)$ and D-alloisoleucine $(A)$, and is expressed as the ratio of these two molecules $(A / I)$. As biologically produced amino acids are almost exclusively L-amino acids, and because the formation of D-alloisoleucine is approximately $30 \%$ more common than $\mathrm{L}$-isoleucine formation, $A / I$ progresses from values close to zero in modern specimens towards equilibrium at a value of about $A / I=1.3$ (Williams and Smith, 1977; Miller and Brigham-Grette, 1989). Unlike geochronological techniques 
based on measuring the extent and effects of radioactive decay, the rate of isoleucine epimerisation is highly sensitive to temperature. Laboratory experiments predict that in warm settings (e.g., mean temperature of $25^{\circ} \mathrm{C}$ ) a $4{ }^{\circ} \mathrm{C}$ temperature increase will double the rate of epimerisation (Brooks et al., 1990).

In the context of African archaeology, the geochronological implications of isoleucine epimerisation have been explored extensively using ostrich (Struthio) eggshells (Brooks and Smith, 1987; Brooks et al., 1990; Miller et al., 1991, 1992, 1999a; Henry and Miller, 1992; Miller et al., 1992; Johnson et al., 1997; Kokis et al., 1998). For example, at Equus Cave A/I values indicate that Struthio eggshells have been extensively mixed throughout the sequence (Johnson et al., 1997), and ages inferred from $A / I$ values at Border Cave (Miller et al., 1999a) and Gi (Brooks et al., 1990) exhibit an excellent correspondence with independent numeric ages (Grün and Beaumont, 2001; Bird et al., 2003). Such applications are strengthened by criteria for the identification of eggshells with an anomalous thermal history produced by exposure to the high temperatures associated with campfire heating events (Miller et al., 1992). In non-archaeological contexts, ages inferred from the $A / I$ values in eggshells of Australian birds (the emu Dromaius, the extinct giant mihirung Genyornis, and water-birds) have proven valuable for examining the changing environments and biogeography of central Australia (Magee and Miller, 1998; Johnson et al., 1999; Miller et al., 1999b).

Given the demonstrated ability to extract reliable geochronological information from eggshell amino acids, we have pursued the possibility of using the extent of isoleucine epimerisation as a proxy for geological time in Australasian archaeological sites. We report here $A / I$ values in eggshells from Toé and Kria caves (located near the Ayamaru Lakes, Papua, Indonesia), and Hay Cave (Mitchell-Palmer limestone towers of northern Queensland, Australia) (Fig. 1). Preliminary results on the Ayamaru

(a) Northern Australasia

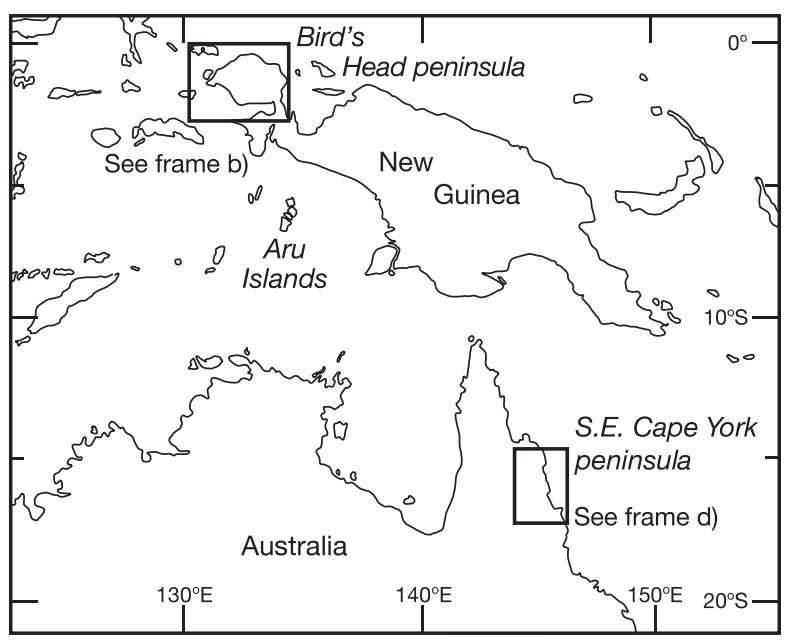

(b) The Bird's Head peninsula

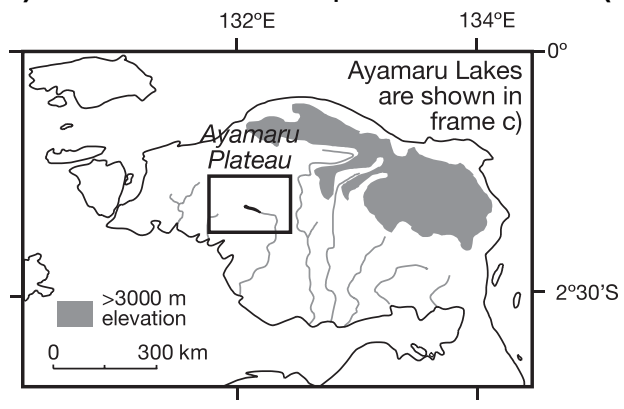

(c)

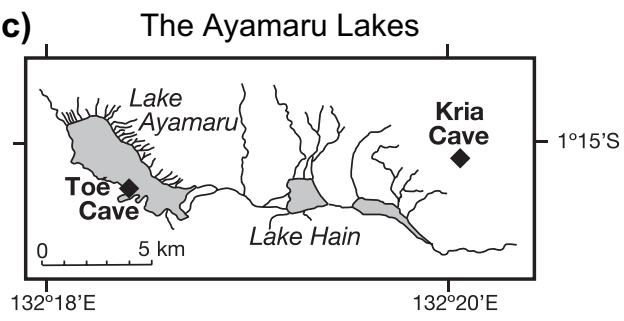

(d) Southeast Cape York peninsula

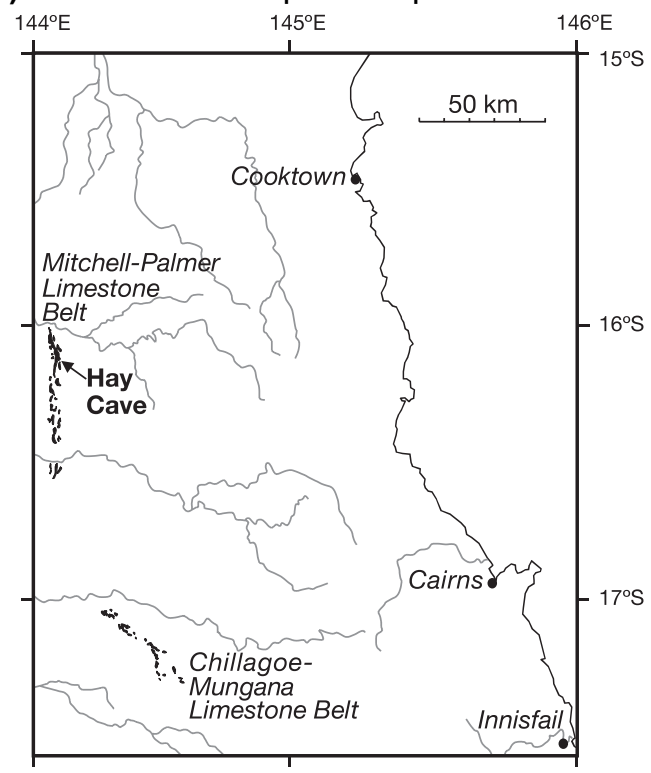

Fig. 1. Location maps for the study sites. Maps depict (a) northern Australasia and locations of the study sites, (b) the Bird's Head peninsula, (c) the location of Toé and Kria Caves with respect to the Ayamaru Lakes, and (d) the location of Hay Cave in the Mitchell-Palmer limestone belt of southeast Cape York peninsula. 
Lakes eggshells were reported by Pasveer et al. (2002) and Pasveer (2004). The aim of the research is to compare $A / I$ values to independent forms of geochronological control (stratigraphic trends, radiocarbon ages) in order to assess relationships between the reaction extent and time. Combined with a recent report on $A / I$ values in cassowary eggshells from the Aru Islands (Clarke and Miller, 2005), the present research on cassowary and megapode eggshells from Australasian archaeological sites represents a significant increase in the taxonomic and geographic application of eggshell isoleucine epimerisation geochronology.

\section{Materials and methods}

\subsection{Specimen identification}

Thick (ca. $1 \mathrm{~mm}$ ) fragments of eggshell attributed to the cassowary (Casuarius spp.) were recovered from the Ayamaru Lakes sites. Casuarius is a large, flightless, frugivorous bird that inhabits the rainforests of New Guinea, northeastern Australia and neighbouring islands (Rich et al., 1988). Any of the three extant species of Casuarius (C. casuarius, C. unappendiculatus and $C$. bennetti) are potentially represented amongst the eggshells. Thin (ca. $0.3-0.4 \mathrm{~mm}$ ) eggshells were also recovered from the Ayamaru Lakes sites, and from Hay Cave. These thin eggshells are attributed to the megapodes, a family of birds found throughout southeast Asia, Australia, Papua New Guinea and the western Pacific, that are renowned for their use of environmental heat to incubate their eggs (Jones et al., 1995). Megapodes possibly represented amongst the Ayamaru Lakes eggshells include Megapodius, Talegalla and Aepypodius (Jones et al., 1995; Aplin, 1998). The Hay Cave eggshells are attributed to the Australian brush-turkey, Alectura lathami (Clarke, 2005). Collections were screened to target large fragments and to avoid discoloured or darkened eggshells as these may have been exposed to high temperatures.

\subsection{Isoleucine epimerisation analyses}

To isolate amino acids of the squamatic zone the outer and inner surface of Casuarius eggshells were removed by abrasion. Megapode eggshells were cleaned of adhering sediments but were not abraded due to their fragility. Thirty-three percent of the exterior surface of eggshells was removed with $2 \mathrm{~N} \mathrm{HCl}$ and a fragment weighing between 4 and $14 \mathrm{mg}$ was dissolved in $7 \mathrm{~N} \mathrm{HCl}$ and heated at $110{ }^{\circ} \mathrm{C}$ for $22 \mathrm{~h}$ to hydrolyse peptide bonds and obtain free amino acids. The hydrolysed residue was desiccated then re-hydrated with $0.01 \mathrm{~N} \mathrm{HCl}$ prior to analysis. D-Alloisoleucine and L-isoleucine were separated by liquid chromatography and the output was interpreted using ChemStation software.

The extent of isoleucine epimerisation is the ratio of the relative abundance of D-alloisoleucine to L-isoleucine $(A / I)$ calculated using peak areas. The reported values are averages accompanied by an estimate of analytical uncertainty ( \pm 1 standard deviation (SD)) based on two or more replicates on the same sample preparation: the average uncertainty is \pm 0.005 .
A correction factor based on peak width at half peak height was applied to the area data to account for possible errors in the determination of the elution times of the two peaks (especially where $A$ is small), such that:

$$
A / I=A_{\text {area }} / I_{\text {area }} \times A_{\text {width }} / I_{\text {width }}
$$

Typically, the D-alloisoleucine and L-isoleucine peaks are congruent so the correction factor produces an $A / I$ value only slightly different (within two standard deviations) of that calculated for the more commonly used peak height data. To correct for batch effects the $A / I$ values have been normalised to an internal series of $A / I$ values. These batch effects are discussed in detail elsewhere (Clarke, 2005).

\subsection{Radiocarbon age estimation}

Eggshells that exhibited low $A / I$ values relative to eggshells recovered from similar depths were selected for radiocarbon dating (although some with apparently elevated $A / I$ values were submitted before this protocol was established). At Toé Cave there is a bias towards eggshells from the base of the sequence because we sought to confirm the Pleistocene antiquity of the occupation of the site (Pasveer et al., 2002). Preparation of eggshell calcite for radiocarbon dating was identical to that for amino acid analyses (except the acid etch was increased to remove $50 \%$ of the eggshell calcite). Conventional radiocarbon ages (BP, with 1950 as the base year) are reported corrected for isotopic fractionation and converted to calendar years (cal years BP) using CALIB 4.3 (Stuiver and Reimer, 1993). A southern hemisphere correction was not considered appropriate for the low latitude study sites. Where conventional ages exceeded 18,000 years BP calendar ages were estimated using the calibration curve of Hughen et al. (2004).

\section{Results}

\subsection{Toé Cave}

Toé Cave is located inside a low conical hill, situated on a small peninsula that juts into the southern margin of the western basin of the Ayamaru Lakes ( $1^{\circ} 15^{\prime} \mathrm{S} ; 132^{\circ} 15^{\prime} \mathrm{E}$, Fig. 1c). Johan Jelsma excavated the site in 1995 and reports are provided by Jelsma (1998) and Pasveer (2004). The mean annual temperature of the Ayamaru Lakes region is about $25^{\circ} \mathrm{C}$. The cave has several entrances, one of which was excavated to bedrock. This entrance is $c a .3 \mathrm{~m}$ wide and $3 \mathrm{~m}$ high. The surface in this area is approximately horizontal but about $2.5 \mathrm{~m}$ from the entrance it slopes towards the back of the cave. At the horizontal part of the entrance three $1 \mathrm{~m}^{2}$ squares were excavated in $5 \mathrm{~cm}$ depth intervals, forming a transect between the opposing walls. This excavated area contains a deposit up to $140 \mathrm{~cm}$ deep within which two main units were identified. The lower one-third of the deposit is a Pleistocene unit, the upper twothirds are of Holocene age. The nature of the transition between these two units could not be established. Detailed analyses of the archaeological material and radiocarbon ages have led to 
the conclusion that the deposit is essentially intact, albeit with minor local slumping and infill (Pasveer, 2004). Ages obtained on eggshells from the square against the northern wall of the cave (square 2N1E) are in the order expected with respect to depth in the deposit, although three Pleistocene ages with a range greater than $c a .15,000$ years were found in the same depth interval (Table 1, Fig. 2). However, this is not surprising given the thinness $(30 \mathrm{~cm})$ of the Pleistocene unit at this side of the cave. Other radiocarbon ages came from samples in the square located against the southern wall (1SOE) (see Table 1, Fig. 2 and Jelsma, 1998). Three of these ages were obtained on charcoal and are sub-recent and probably reflect contamination or intrusion. The other two were obtained on fragments of bone and eggshell, and although considered reliable, were younger than expected of samples from the depths from which they were obtained and might be the result of local slumping or erosion of the sediment.

The A/I values of Casuarius and megapode eggshells from Toé Cave are reported in Table 2. In Fig. 2 the A/I values are plotted against the depth from which the specimens were recovered in the Toé Cave profile, and in Fig. 3a the frequency distribution of these values is presented. The expected trend of a gradual, well-defined increase in Casuarius A/I values $(n=34)$ reflecting an increase in eggshell age with respect to depth was not observed. Instead, A/I values amongst eggshells recovered from similar depths exhibited a wide range. The greatest range $(0.296 \leq A / I \leq 1.024)$ occurred at a depth of approximately $70 \mathrm{~cm}$. A large range of values $(0.420 \leq A$ / $I \leq 0.989)$ was also observed amongst eggshells from the base of the excavation $(95-100 \mathrm{~cm})$. Age accounts for some of the variability in $A / I$ values observed at the base of the sequence: radiocarbon ages for specimens from the base of the excavation ranged from approximately 15,500 to $30,000 \mathrm{cal}$ years BP (Fig. 2).

Of the few $(n=7)$ Toé Cave megapode eggshells analysed many had A/I values less than those of Casuarius eggshells from similar depths. However, as a whole, the megapode eggshell $A / I$ values exhibit the same problematic trends observed in the Casuarius eggshell dataset (Fig. 2). Again, the expected trend with respect to depth is replaced by wide scatter amongst $A / I$ values of eggshells from similar depths (e.g., $0.131 \leq A /$ $I \leq 1.098$ at approximately $50 \mathrm{~cm}$ depth).

\subsection{Kria Cave}

Kria Cave (Fig. 1c) was excavated by J.M. Pasveer in 1995 (Pasveer, 1998, 2004). The cave has several entrances, one of which has accumulated over $2 \mathrm{~m}$ of sediment. This entrance is ca. $3 \mathrm{~m}$ high, $6 \mathrm{~m}$ wide and $2.5 \mathrm{~m}$ deep. Excavation took place in two $1 \mathrm{~m}^{2}$ squares using $5 \mathrm{~cm}$ depth intervals. The deposit has a largely undisturbed stratigraphic profile, an observation supported by 9 of the 11 radiocarbon ages obtained on samples from the site (two were anomalously young, Fig. 4). Five occupation units were identified; the four lower occupation units differ from each other in terms of quantities of material (mostly stone and bone artefacts and large quantities of faunal remains), while the top unit contains different material and in

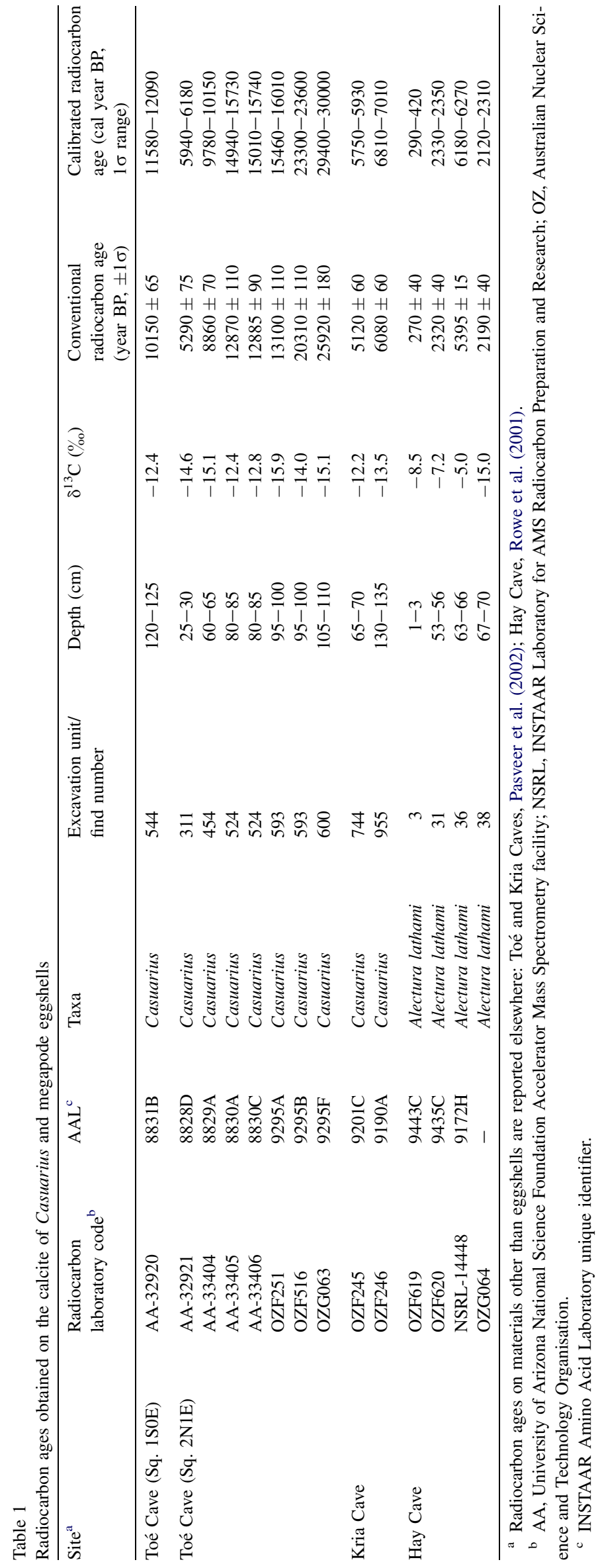



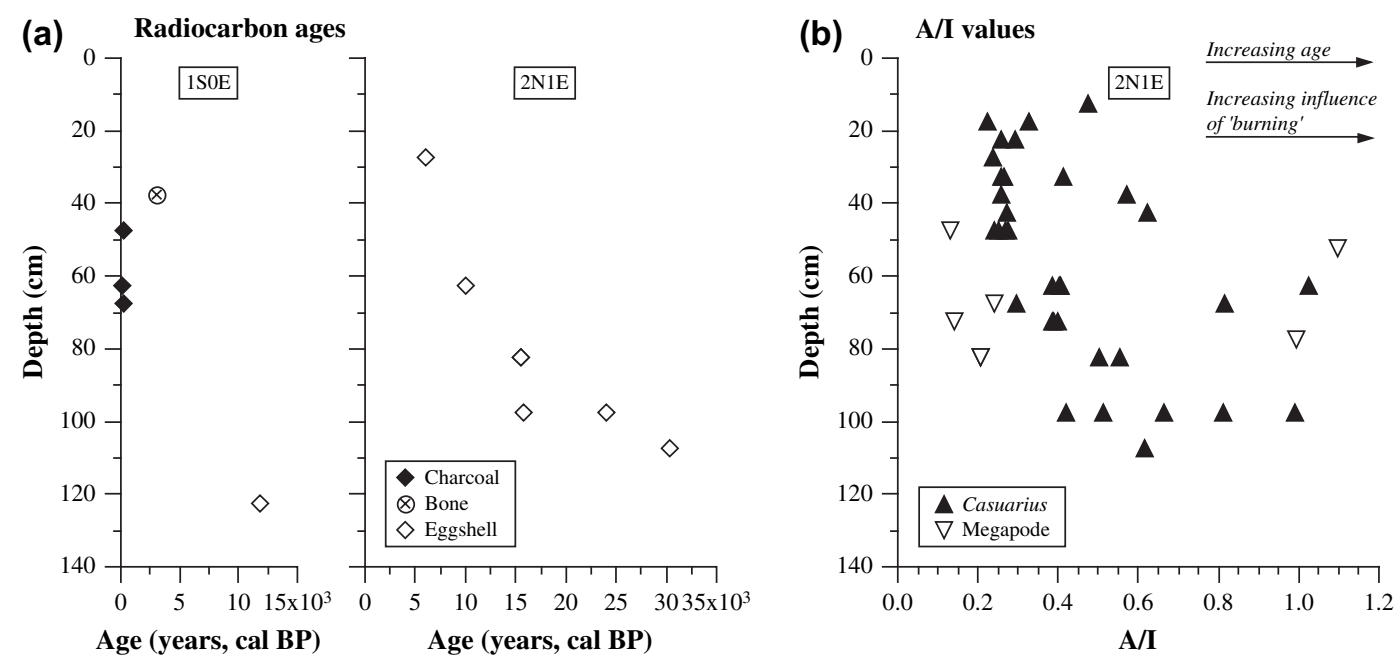

Fig. 2. Toé Cave (a) radiocarbon ages for excavation squares $1 \mathrm{~S} 0 \mathrm{E}$ and $2 \mathrm{~N} 1 \mathrm{E}$ and (b) Casuarius and megapode eggshells A/I values for 2N1E. The bone and charcoal radiocarbon ages are those reported by Jelsma (1998). Arrows indicate the direction of expected trends.

much lower quantities. The oldest radiocarbon age from the deepest excavation unit is $c a .7700$ cal years BP. However, not all of the sediment was excavated and the timing of initial occupation can be extrapolated to $c a$. 9000 years ago. The activities in the cave remained essentially the same over the subsequent $c a .4000$ years, after which the site appears to have been abandoned. From a radiocarbon date on a pig bone from the uppermost unit it is inferred that occupation had resumed by about 1800 years ago. There are no clear indications that the cave is in use today and it is uncertain when occupation of the site ceased.

Results for the extent of isoleucine epimerisation in eggshells from Kria Cave are presented in Fig. 4 and compiled in Table 3. As observed at Toé Cave, there is much scatter in the Casuarius and megapode eggshell $A / I$ values. However, in the Fig. $3 \mathrm{~b}$ histogram it is observed that there is a tendency towards lower $A / I$ values at Kria Cave than Toé Cave and this is in accord with the radiocarbon chronologies for the respective sites (Figs. 2 and 4). Low Casuarius eggshell A/I values $(0.15 \leq A / I \leq 0.25)$ are observed across a large span of depths, from about $65 \mathrm{~cm}$ to $140 \mathrm{~cm}$ depth. From this narrow range of $A / I$ values it appears that much of the sequence was deposited over a short period of time. This inference is supported by radiocarbon ages on eggshells from these depths that suggest that it was deposited over approximately 1000 years (Table 1).

\subsection{Hay Cave}

Hay Cave is a large limestone cave located between the Mitchell and Palmer rivers, north Queensland, approximately $140 \mathrm{~km}$ west of the coastline, $16^{\circ} 6^{\prime} \mathrm{S}$ latitude, $144^{\circ} 7^{\prime} \mathrm{E}$ longitude. The cave entrance is large (10 m deep, $16 \mathrm{~m}$ wide and $3 \mathrm{~m}$ high) and it was towards the centre where the floor is flat and sediments are soft that excavations were undertaken by Bruno David, Harry Lourandos and Chris Clarkson in 1996. Four juxtaposed $50 \mathrm{~cm}^{2}$ squares were excavated, the deepest of which (M30) was excavated in 63 lots of $c a$.
$2 \mathrm{~cm}$ units (XU) that followed the stratigraphy. Twenty-two distinct stratigraphic units were identified in the $133 \mathrm{~cm}$ deep excavation and sediments containing cultural materials were found at all depths. From an AMS radiocarbon age of ca. 34,000 cal years BP obtained on a riverine bivalve shell recovered from XU 60 of square M30 $(122-125 \mathrm{~cm}$ below the surface) (David and Lourandos, unpublished) it is estimated that sediments towards the base of the excavation were deposited about 30,000 years ago. However, assessing the timing of the deposition of the $c a .15 \mathrm{~cm}$ of sediment immediately below the major stratigraphic break located at $c a$. $60 \mathrm{~cm}$ depth was problematic. A radiocarbon age of about 3300 cal years BP (OZD009) was obtained on charcoal recovered close to the stratigraphic break, while an age of ca. 13,800 cal years BP was obtained on charcoal from ca. $75 \mathrm{~cm}$ depth (David and Lourandos, unpublished, Rowe et al., 2001). Thus, it was not clear whether or not this section included sediments deposited during the Early to Mid Holocene, especially considering Early Holocene sediments of many other archaeological sites in north Queensland are either absent or mixed (e.g., David and Chant, 1995). Large numbers of land snail shells and high frequencies of calcium carbonate concretions at $c a .60 \mathrm{~cm}$ depth) indicate the likely presence of materials deposited during the Early Holocene at Hay Cave, as this was a period of heightened humidity and both items signal wetter conditions (Rowe et al., 2001). We thus turned to the A/I values of Alectura eggshells to obtain information on the presence of Early to Mid Holocene sediments at Hay Cave.

A total of 99 Alectura eggshells excavated from square M30 of Hay Cave were subjected to amino acid analyses (Table 4, Fig. 5). These eggshells primarily come from the upper $75 \mathrm{~cm}$ of the sequence: below these depths eggshells were rare or absent (Holden, 1999). A fragment of modern Alectura eggshell exhibited an A/I value of $0.021 \pm 0.003$. In Fig. 5 it is observed that $A / I$ in the majority of the eggshells analysed occupied a narrow range of values, from 
Table 2

Extent of isoleucine epimerisation in Casuarius and megapode eggshells from Toé Cave

\begin{tabular}{|c|c|c|c|c|c|}
\hline \multirow[t]{2}{*}{ Square } & \multirow{2}{*}{$\begin{array}{l}\text { Find } \\
\text { number }\end{array}$} & \multirow[t]{2}{*}{ Depth $(\mathrm{cm})$} & \multirow[t]{2}{*}{$\mathrm{AAL}^{\mathrm{a}}$} & \multicolumn{2}{|l|}{$A / I \pm \mathrm{SD}$} \\
\hline & & & & Casuarius & Megapode \\
\hline $1 \mathrm{~S} 0 \mathrm{E}$ & 544 & $120-125$ & $8831 \mathrm{~B}$ & $0.362 \pm 0.008$ & \\
\hline \multirow[t]{41}{*}{$2 \mathrm{~N} 1 \mathrm{E}$} & 204 & $10-15$ & 9277A & $0.476 \pm 0.018$ & \\
\hline & 206 & $15-20$ & $9278 \mathrm{~A}$ & $0.223 \pm 0.001$ & \\
\hline & 206 & $15-20$ & $9278 B$ & $0.328 \pm 0.002$ & \\
\hline & 301 & $20-25$ & 9279A & $0.292 \pm 0.012$ & \\
\hline & 301 & $20-25$ & 9279B & $0.259 \pm 0.003$ & \\
\hline & 311 & $25-30$ & 8828D & $0.237 \pm 0.001$ & \\
\hline & 326 & $30-35$ & 9296A & $0.257 \pm 0.008$ & \\
\hline & 326 & $30-35$ & 9296B & $0.414 \pm 0.008$ & \\
\hline & 326 & $30-35$ & $9296 \mathrm{C}$ & $0.264 \pm 0.004$ & \\
\hline & 342 & $35-40$ & $9280 \mathrm{~A}$ & $0.257 \pm 0.007$ & \\
\hline & 343 & $35-40$ & $9450 \mathrm{~A}$ & $0.571 \pm 0.002$ & \\
\hline & 361 & $40-45$ & $9451 \mathrm{~A}$ & $0.622 \pm 0.006$ & \\
\hline & 361 & $40-45$ & $9451 \mathrm{~B}$ & $0.273 \pm 0.002$ & \\
\hline & 383 & $45-50$ & $9283 \mathrm{~A}$ & $0.240 \pm 0.003$ & \\
\hline & 383 & $45-50$ & 9283B & $0.268 \pm 0.007$ & \\
\hline & 383 & $45-50$ & $9284 \mathrm{~A}$ & & $0.131 \pm 0.001$ \\
\hline & 384 DIV & $45-50$ & $9452 \mathrm{~A}$ & $0.251 \pm 0.001$ & \\
\hline & 384 DIV & $45-50$ & $9452 \mathrm{~B}$ & $0.274 \pm 0.001$ & \\
\hline & 414 & $50-55$ & $9285 \mathrm{~A}$ & & $1.098 \pm 0.022$ \\
\hline & 453 & $60-65$ & $9453 \mathrm{~A}$ & $1.024 \pm 0.005$ & \\
\hline & 454 & $60-65$ & 8829A & $0.384 \pm 0.001$ & \\
\hline & 457 & $60-65$ & 9454B & $0.406 \pm 0.002$ & \\
\hline & 457 & $60-65$ & $9454 \mathrm{C}$ & $0.401 \pm 0.005$ & \\
\hline & 484 & $65-70$ & 9288A & & $0.241 \pm 0.002$ \\
\hline & 485 & $65-70$ & $9455 \mathrm{~A}$ & $0.814 \pm 0.006$ & \\
\hline & 485 & $65-70$ & 9455B & $0.296 \pm 0.007$ & \\
\hline & 499 & $70-75$ & 9289A & & $0.141 \pm 0.002$ \\
\hline & 500 & $70-75$ & $9456 \mathrm{~A}$ & $0.398 \pm 0.004$ & \\
\hline & 500 & $70-75$ & 9456B & $0.385 \pm 0.001$ & \\
\hline & 500 & $70-75$ & $9456 \mathrm{C}$ & $0.388 \pm 0.001$ & \\
\hline & 516 & $75-80$ & 9291A & & $0.992 \pm 0.015$ \\
\hline & 523 & $80-85$ & $9457 \mathrm{~A}$ & & $0.206 \pm 0.012$ \\
\hline & 523 & $80-85$ & 9457B & & $0.205 \pm 0.003$ \\
\hline & 524 & $80-85$ & $8830 \mathrm{~A}$ & $0.501 \pm 0.001$ & \\
\hline & 524 & $80-85$ & $8830 \mathrm{C}$ & $0.553 \pm 0.001$ & \\
\hline & 593 & $95-100$ & $9295 \mathrm{~A}$ & $0.420 \pm 0.011$ & \\
\hline & 593 & $95-100$ & 9295B & $0.514 \pm 0.013$ & \\
\hline & 593 & $95-100$ & $9295 \mathrm{C}$ & $0.989 \pm 0.006$ & \\
\hline & 593 & $95-100$ & 9295D & $0.665 \pm 0.005$ & \\
\hline & 593 & $95-100$ & $9295 \mathrm{E}$ & $0.813 \pm 0.001$ & \\
\hline & 600 & $105-110$ & $9295 \mathrm{~F}$ & $0.617 \pm 0.007$ & \\
\hline
\end{tabular}

a INSTAAR Amino Acid Laboratory code.

those expected of modern specimens up to $A / I=0.16$. Only two specimens (2\%) exceeded this range. High variation was typically observed at stratigraphic boundaries (reflecting mixing of eggshells of differing ages) and where eggshells with anomalously low $A / I$ values were occasionally recovered from the same excavation unit as eggshells with higher values. In the frequency distribution of these results (Fig. 6) the values fall into three clusters: $0.02<A$ / $I<0.05,0.05<A / I<0.08$, and $0.13<A / I<0.16$. These clusters are identified as $\mathrm{A}, \mathrm{B}$, and $\mathrm{C}$, respectively. Not incorporated in these three clusters are the $A / I$ values of three eggshells, one of which falls between clusters B and C. The other two have $A / I$ values greater than those observed in cluster $\mathrm{C}$. (a)

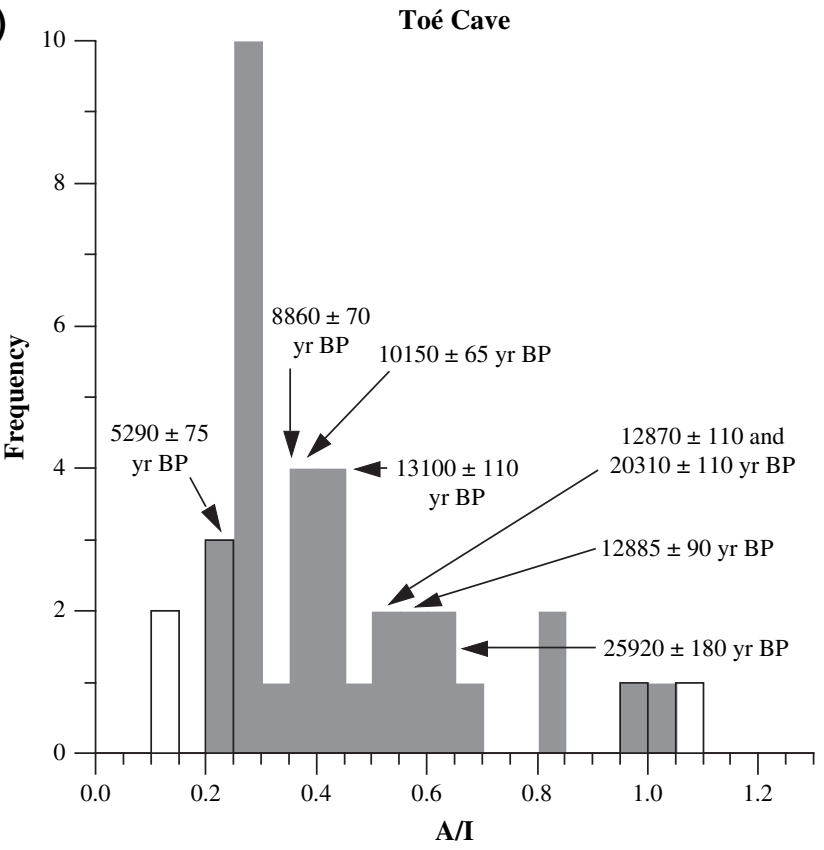

(b)

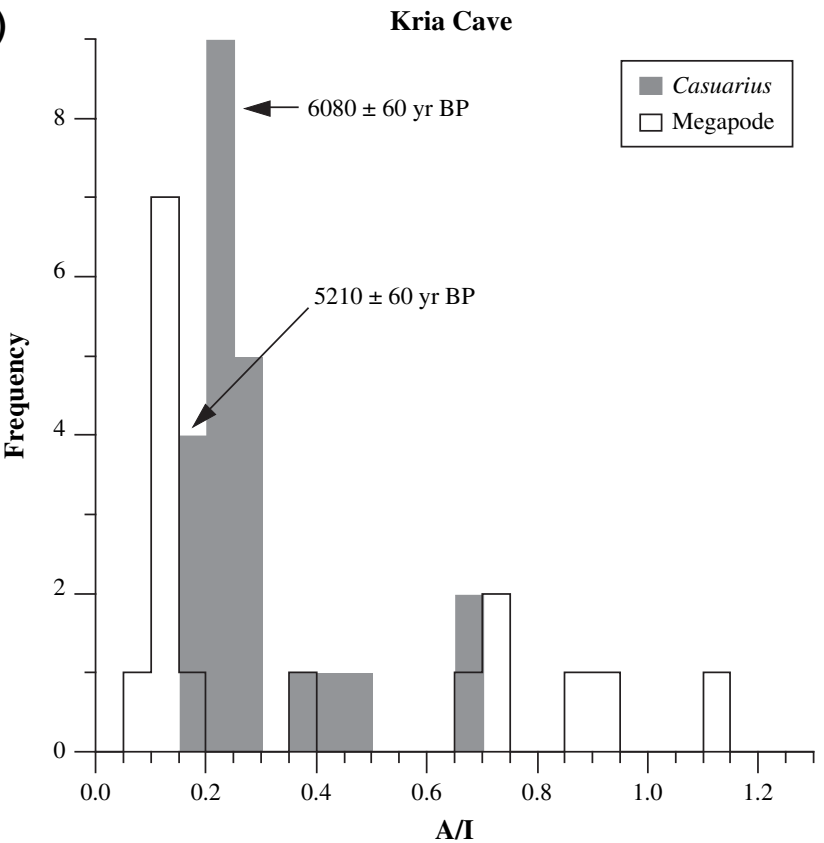

Fig. 3. Histogram of (a) Toé Cave and (b) Kria Cave Casuarius and megapode eggshell $A / I$ values. Radiocarbon ages obtained on Casuarius eggshells are indicated. Because the rate of isoleucine epimerisation is expected to differ between the two taxa the data are superposed.

\section{Discussion}

\subsection{Highly variable Casuarius and megapode eggshell A/I values from Toé and Kria caves}

The influence of high temperatures associated with campfire heating events is the mechanism most likely to be responsible for the high variability in Casuarius and megapode eggshell A/I values amongst specimens excavated from similar depths in the Toé and Kria Cave sequences. At Kria Cave mixing is an 

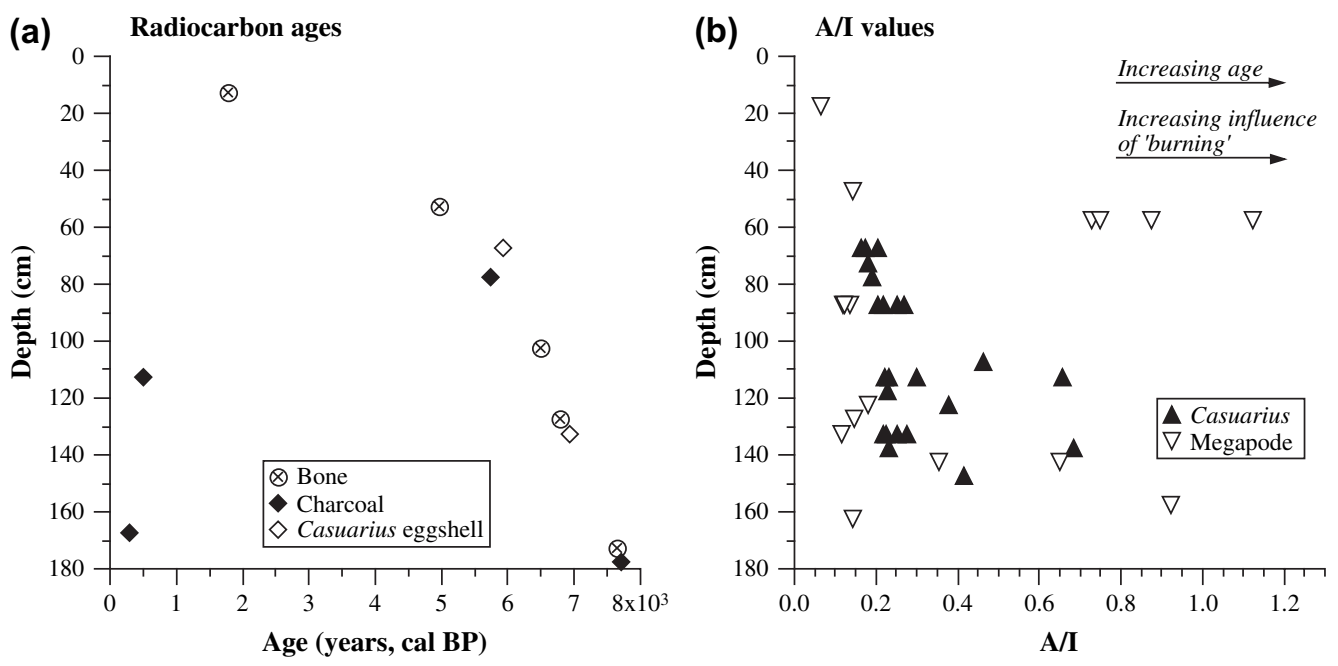

Fig. 4. Kria Cave (a) radiocarbon ages and (b) Casuarius and megapode eggshell A/I values. The bone and charcoal radiocarbon ages are those reported by Pasveer and Aplin (1998). Arrows indicate the direction of expected trends.

unsatisfactory explanation for the variability in $A / I$ values because the eggshell calcite radiocarbon ages are in accord with other radiometric dates for the sequences (Fig. 4). Similarly, at Toé Cave the eggshell radiocarbon ages are in accord with the timing of the deposition of the sequence as expected from changes in the archaeofauna assemblage with respect to depth (Jelsma, 1998; Pasveer and Aplin, 1998; Pasveer, 2004).

Within a stratigraphic unit eggshells unaffected or least affected by 'burning' are expected to exhibit the lowest $A / I$ values and the scatter of $A / I$ values between these minima and equilibrium $(A / I=1.3)$ will reflect the effect of high temperature on the rate of epimerisation. The degree to which exposure to campfires inflates the extent of isoleucine epimerisation is also a function of the duration of the heating event, the $A / I$ value at the time of the event, and the number of such heating events encountered. Thus, according to the response of the reaction system to burning, the most coherent geochronological information is expected from eggshells with low $A / I$ values relative to those exhibited by eggshells excavated from similar depths (where mixing is not significant). Indeed, at both Ayamaru Plateau caves the relatively low Casuarius eggshell $A / I$ values slowly increase with depth and at both sites the relative age-depth trend is comparable to the respective radiocarbon numeric age-depth trend. For example, amongst eggshells with relatively low $A / I$ values, results of $A / I<0.2$ are observed at both caves amongst sediments with Holocene radiocarbon ages, and results between $A / I=0.3$ and $A / I=0.4$ are observed at Toé Cave where eggshells exhibit Pleistocene radiocarbon ages.

High temperatures associated with campfires will always be a concern when interpreting the biogeochemistry of ancient Casuarius and megapode eggshells. This is because, unlike those of other large flightless birds (Dromaius, Struthio and Genyornis) subjected to isoleucine epimerisation analyses, they will almost always be obtained from archaeological sites (megapode nesting mounds thousands of years old have been identified (e.g., Stocker, 1971; Bowman et al., 1999) but eggshell fragments have not been found in them). The $A / I$ values are not likely to be spurious artefacts of preservation state because the amino acid concentrations indicate that diagenesis has taken place in a regular manner, although like the extent of isoleucine epimerisation, it has been accelerated in some eggshells and not in others (Clarke, 2005). Also supporting the integrity of the amino acid results is the contrast in rates of isoleucine epimerisation between megapode and Casuarius eggshells at the Ayamaru Lakes archaeological sites. The tendency for megapode eggshells to exhibit $A / I$ values less than those of Casuarius eggshells recovered from similar depths is in accord with laboratory heating experiments (Clarke, 2005) that predict that at $25^{\circ} \mathrm{C}$ the rate of isoleucine epimerisation in Casuarius eggshells should be approximately half that in megapode eggshells.

The influence of campfire heating events on the extent of amino acid racemisation has previously been noted. MurrayWallace and Colley (1997) observed elevated Asx $D / L$ values attributable to transient exposure to high temperatures in mollusc shells from a Late Holocene archaeological sequence. Approximately $40 \%$ of the land snail shells from Hinds Cave analysed by Goodfriend and Ellis (2000) were deemed unsuitable for isotope analyses due to heating after rejecting samples with unacceptably high $A / I$ values. 'Burnt' Struthio eggshells have often been encountered in Pleistocene archaeological sites throughout southern Africa. At the archaeological site of Boomplaas, South Africa, Hare et al. (1993) observed Struthio eggshells with an anomalously high extent of racemisation that was attributed to 'burning' on the basis of elevated abundances of amines and ammonia. A little less than half of the Struthio eggshells analysed by Miller et al. (1999a) from Border Cave (47\%) and Apollo 11 Cave (45\%) were identified as exposed to high temperatures by solving simultaneous equations for the extent of leucine hydrolysis and isoleucine epimerisation. Similarly, approximately half of the Struthio eggshells from Honey Nest Cave analysed by Miller et al. (1992) were identified as 'burnt' by this method and confirmed by subsequent ${ }^{14} \mathrm{C}$ dating. 'Burning' therefore seems to be a problem that often complicates the extraction 
Table 3

Extent of isoleucine epimerisation in Casuarius and megapode eggshells from Kria Cave

\begin{tabular}{|c|c|c|c|c|}
\hline \multirow{2}{*}{$\begin{array}{l}\text { Find } \\
\text { number }\end{array}$} & \multirow[t]{2}{*}{ Depth $(\mathrm{cm})$} & \multirow[t]{2}{*}{$\mathrm{AAL}^{\mathrm{a}}$} & \multicolumn{2}{|l|}{$A / I \pm \mathrm{SD}$} \\
\hline & & & Casuarius & Megapode \\
\hline $643 / 646$ & $15-20$ & $9204 \mathrm{~A}$ & & $0.066 \pm 0.002$ \\
\hline 712 & $45-50$ & $9203 \mathrm{~A}$ & & $0.144 \pm 0.001$ \\
\hline 723 & $55-60$ & $9202 \mathrm{~A}$ & & $0.728 \pm 0.004$ \\
\hline 723 & $55-60$ & $9202 \mathrm{C}$ & & $0.747 \pm 0.040$ \\
\hline 723 & $55-60$ & 9202B & & $0.875 \pm 0.033$ \\
\hline 723 & $55-60$ & 9202D & & $1.122 \pm 0.053$ \\
\hline 744 & $65-70$ & $9201 \mathrm{~A}$ & $0.205 \pm 0.010$ & \\
\hline 744 & $65-70$ & 9201B & $0.172 \pm 0.001$ & \\
\hline 744 & $65-70$ & $9201 C$ & $0.165 \pm 0.001$ & \\
\hline 756 & $70-75$ & $9200 \mathrm{~A}$ & $0.180 \pm 0.011$ & \\
\hline 766 & $75-80$ & 9199A & $0.191 \pm 0.006$ & \\
\hline 792 & $85-90$ & $9198 \mathrm{~A}$ & $0.203 \pm 0.012$ & \\
\hline 792 & $85-90$ & 9198B & $0.217 \pm 0.002$ & \\
\hline 792 & $85-90$ & $9198 \mathrm{C}$ & $0.252 \pm 0.007$ & \\
\hline 792 & $85-90$ & 9198D & $0.269 \pm 0.013$ & \\
\hline 792 & $85-90$ & 9197A & & $0.119 \pm 0.013$ \\
\hline 792 & $85-90$ & 9197B & & $0.136 \pm 0.001$ \\
\hline 792 & $85-90$ & $9197 \mathrm{C}$ & & $0.122 \pm 0.004$ \\
\hline 852 & $105-110$ & 9196A & $0.464 \pm 0.003$ & \\
\hline 865 & $110-115$ & $9195 \mathrm{~A}$ & $0.232 \pm 0.001$ & \\
\hline 865 & $110-115$ & 9195B & $0.656 \pm 0.003$ & \\
\hline 865 & $110-115$ & $9195 \mathrm{C}$ & $0.221 \pm 0.008$ & \\
\hline 865 & $110-115$ & 9195D & $0.299 \pm 0.001$ & \\
\hline 896 & $115-120$ & $9193 \mathrm{~A}$ & $0.228 \pm 0.001$ & \\
\hline 913 & $120-125$ & $9192 \mathrm{~A}$ & $0.378 \pm 0.015$ & \\
\hline 913 & $120-125$ & $9458 \mathrm{~A}$ & & $0.181 \pm 0.005$ \\
\hline 941 & $125-130$ & $9191 \mathrm{~A}$ & & $0.145 \pm 0.002$ \\
\hline 955 & $130-135$ & $9190 \mathrm{~A}$ & $0.225 \pm 0.009$ & \\
\hline 955 & $130-135$ & 9190B & $0.253 \pm 0.004$ & \\
\hline 955 & $130-135$ & $9190 \mathrm{C}$ & $0.275 \pm 0.002$ & \\
\hline 955 & $130-135$ & 9190D & $0.219 \pm 0.005$ & \\
\hline 980 & $130-135$ & $9189 \mathrm{~A}$ & & $0.117 \pm 0.008$ \\
\hline 982 & $135-140$ & $9188 \mathrm{~A}$ & $0.232 \pm 0.005$ & \\
\hline 1005 & $135-140$ & $9187 \mathrm{~A}$ & $0.683 \pm 0.005$ & \\
\hline 1008 & $140-145$ & $9186 \mathrm{~A}$ & & $0.354 \pm 0.001$ \\
\hline 1008 & $140-145$ & 9186B & & $0.650 \pm 0.008$ \\
\hline 1035 & $145-150$ & $9185 \mathrm{~A}$ & $0.415 \pm 0.008$ & \\
\hline 1084 & $155-160$ & $9184 \mathrm{~A}$ & & $0.921 \pm 0.002$ \\
\hline 1109 & $160-165$ & $9183 \mathrm{~A}$ & & $0.142 \pm 0.013$ \\
\hline
\end{tabular}

${ }^{\text {a }}$ INSTAAR Amino Acid Laboratory code.

of geochronological information from the amino acid biogeochemistry of fossils in archaeological contexts.

\subsection{Coherent trends in Hay Cave eggshell A/I values}

In the frequency distribution of the 99 Hay Cave $A / I$ values (Fig. 6) there are two eggshells with atypically high $A / I$ values. A relatively high $A / I$ value (AAL9171A, $A / I=0.333$ ) was exhibited by an eggshell recovered near the top of the excavation, amongst eggshells where $A / I<0.04$. The other relatively high $A / I$ value (AAL10086A, $A / I=0.218$ ) is also anomalous relative to the values observed in eggshells recovered from similar depths (Fig. 5). Therefore, like the Toé and Kria Cave results, the Hay Cave dataset appears to contain eggshells with anomalously warm thermal histories.

The three clusters of $A / I$ values identified in the Hay Cave results exhibit an excellent but imperfect correlation with the stratigraphic units in this sequence. Of the $A / I$ values that do not conform to the depths that host the majority of eggshells of their respective cluster, all but one was recovered below the typical depth. While bioturbation is a potential explanation for the location of eggshells lower in the Hay Cave profile than expected, the likelihood of this process is reduced by the fragility of the thin megapode eggshells which makes them unlikely to withstand disturbance. Excavation error (such as fragments dropping from the walls of the excavation) in dark, cramped conditions is considered a more likely explanation for the occurrence of young eggshells low in the sequence. This is despite the implementation of precautions to protect the excavated surface from contamination between sessions of excavation.

The radiocarbon chronology indicates that the upper $80 \mathrm{~cm}$ of the sequence was deposited during one of three time periods, the terminal Pleistocene, 2400-3400 cal years BP, and 300900 cal years BP. Similarly, the Alectura eggshell A/I results indicate that the upper $80 \mathrm{~cm}$ can be divided into the clusters, A, B and $\mathrm{C}$. That clusters $\mathrm{A}$ and $\mathrm{B}$ correspond with the two younger phases identifiable by the radiocarbon chronology is supported by paired amino acid-eggshell calcite radiocarbon ages (Table 1, Fig. 6) and the observation that the depth the clusters occupy correspond with the depths from which the radiocarbon samples of David and Lourandos (unpublished) and Rowe et al. (2001) were recovered, with the lower $A / I$ values corresponding to the younger radiocarbon ages (Fig. 5).

Although the age of clusters A and B may be unambiguous, the age of eggshells in cluster $\mathrm{C}$ is unclear for two reasons. First, there is not a paired amino acid-radiocarbon analysis for an eggshell from cluster C. Second, defining the age of the eggshells on stratigraphic grounds is complicated by the occurrence of the cluster at a major stratigraphic break (Fig. 5). The likely age for the cluster is greater than 3500 cal years BP and perhaps younger than the next oldest radiocarbon date, ca. 14,000 cal years BP (OZD943).

It is unlikely that the $A / I$ values of cluster $\mathrm{C}$ eggshells are an artefact of exposure to a campfire heating event for several reasons. First, the fragments were not discoloured as might be expected of eggshells exposed to high temperatures. Second, the extent of isoleucine epimerisation is low $(A / I<0.16)$ and only slightly higher than those of cluster B: if heating has taken place the effect has been subtle. Third, the range in $A / I$ values is small (0.03 $A / I$ units) and this is opposite to the effect expected of exposure to high temperatures. If the rate of isoleucine epimerisation had accelerated due to exposure to high temperatures we would expect greater variability due to the heterogeneity of temperatures within a campfire and variability in the length of time these heat sources act upon the fragments. Therefore we are confident the $A / I$ values of cluster $\mathrm{C}$ primarily relate to the age of the eggshell fragments.

\subsection{Assessing the age of cluster $C$ from A/I values}

In the absence of independent geochronological control for cluster $\mathrm{C}$, estimation of the rate of isoleucine epimerisation in 
Table 4

Extent of isoleucine epimerisation in Alectura lathami eggshells from Hay Cave

\begin{tabular}{|c|c|c|c|c|}
\hline $\begin{array}{l}\text { Excavation } \\
\text { unit }\end{array}$ & $\begin{array}{l}\text { Mean depth } \\
\text { (cm) }\end{array}$ & $\mathrm{AAL}^{\mathrm{a}}$ & $\mathrm{SID}^{\mathrm{b}}$ & $A / I \pm \mathrm{SD}$ \\
\hline 2 & 1.3 & 9178 & $\begin{array}{l}\text { A } \\
\text { B } \\
\text { C } \\
\text { D } \\
\text { E }\end{array}$ & $\begin{array}{l}0.029 \pm 0.006 \\
0.024 \pm 0.001 \\
0.023 \pm 0.001 \\
0.023 \pm 0.005 \\
0.021 \pm 0.004\end{array}$ \\
\hline 3 & 3.1 & 9443 & $\begin{array}{l}\text { A } \\
\text { B } \\
\text { C } \\
\text { D } \\
\text { E }\end{array}$ & $\begin{array}{l}0.025 \pm 0.002 \\
0.025 \pm 0.004 \\
0.021 \pm 0.008 \\
0.021 \pm 0.003 \\
0.020 \pm 0.004\end{array}$ \\
\hline 5 & 6.2 & 9177 & A & $0.333 \pm 0.006$ \\
\hline 7 & 10.2 & 9442 & $\begin{array}{l}\text { A } \\
\text { B } \\
\text { C } \\
\text { D } \\
\text { E }\end{array}$ & $\begin{aligned} 0.025 & \pm 0.006 \\
0.033 & \pm 0.001 \\
0.045 & \pm 0.002 \\
0.026 & \pm 0.001 \\
0.028 & \pm 0.002\end{aligned}$ \\
\hline 11 & 14.6 & 9176 & A & $0.029 \pm 0.002$ \\
\hline $13 \mathrm{~A}$ & 18.4 & 9441 & $\begin{array}{l}\text { A } \\
\text { B } \\
\text { C } \\
\text { D } \\
\text { E }\end{array}$ & $\begin{array}{l}0.038 \pm 0.009 \\
0.027 \pm 0.001 \\
0.025 \pm 0.002 \\
0.025 \pm 0.001 \\
0.025 \pm 0.001\end{array}$ \\
\hline 14 & 19.5 & 9175 & $\begin{array}{l}\text { A } \\
\text { B } \\
\text { C } \\
\text { D } \\
\text { E }\end{array}$ & $\begin{array}{l}0.032 \pm 0.001 \\
0.032 \pm 0.004 \\
0.025 \pm 0.002 \\
0.029 \pm 0.003 \\
0.026 \pm 0.001\end{array}$ \\
\hline 17 & 26.0 & 9440 & $\begin{array}{l}\text { A } \\
\text { B } \\
\text { C } \\
\text { D } \\
\text { E }\end{array}$ & $\begin{array}{l}0.026 \pm 0.001 \\
0.032 \pm 0.002 \\
0.030 \pm 0.004 \\
0.031 \pm 0.001 \\
0.037 \pm 0.004\end{array}$ \\
\hline 18 & 27.4 & 9439 & A & $0.041 \pm 0.011$ \\
\hline 21 & 33.1 & 9438 & $\begin{array}{l}\text { A } \\
\text { B } \\
\text { C } \\
\text { D } \\
\text { E }\end{array}$ & $\begin{array}{l}0.031 \pm 0.003 \\
0.033 \pm 0.008 \\
0.030 \pm 0.005 \\
0.032 \pm 0.003 \\
0.035 \pm 0.008\end{array}$ \\
\hline 22 & 35.6 & 9437 & $\begin{array}{l}\text { A } \\
\text { B } \\
\text { C } \\
\text { D } \\
\text { E }\end{array}$ & $\begin{aligned} 0.029 & \pm 0.002 \\
0.037 & \pm 0.006 \\
0.031 & \pm 0.004 \\
0.033 & \pm 0.004 \\
0.039 & \pm 0.003\end{aligned}$ \\
\hline 24 & 40.2 & 9174 & $\begin{array}{l}\text { A } \\
\text { B } \\
\text { C } \\
\text { D } \\
\text { E }\end{array}$ & $\begin{array}{l}0.028 \pm 0.001 \\
0.030 \pm 0.002 \\
0.037 \pm 0.002 \\
0.040 \pm 0.002 \\
0.056 \pm 0.001\end{array}$ \\
\hline 25 & 42.3 & 9436 & $\begin{array}{l}\text { A } \\
\text { B } \\
\text { C } \\
\text { D } \\
\text { E }\end{array}$ & $\begin{array}{l}0.042 \pm 0.005 \\
0.031 \pm 0.006 \\
0.039 \pm 0.007 \\
0.043 \pm 0.008 \\
0.037 \pm 0.005\end{array}$ \\
\hline 26 & 43.9 & 10082 & $\begin{array}{l}\text { A } \\
\text { B }\end{array}$ & $\begin{array}{l}0.030 \pm 0.002 \\
0.053 \pm 0.002\end{array}$ \\
\hline
\end{tabular}

Table 4 (continued)

\begin{tabular}{|c|c|c|c|c|}
\hline $\begin{array}{l}\text { Excavation } \\
\text { unit }\end{array}$ & $\begin{array}{l}\text { Mean depth } \\
(\mathrm{cm})\end{array}$ & $\mathrm{AAL}^{\mathrm{a}}$ & $\operatorname{SID}^{\mathrm{b}}$ & $A / I \pm \mathrm{SD}$ \\
\hline 27 & 46.0 & 10083 & $\begin{array}{l}\mathrm{A} \\
\mathrm{B}\end{array}$ & $\begin{array}{l}0.057 \pm 0.004 \\
0.039 \pm 0.001\end{array}$ \\
\hline 28 & 47.2 & 10084 & $\begin{array}{l}\mathrm{A} \\
\mathrm{B}\end{array}$ & $\begin{array}{l}0.053 \pm 0.002 \\
0.054 \pm 0.001\end{array}$ \\
\hline 29 & 50.5 & 9173 & $\begin{array}{l}\text { A } \\
\text { B } \\
\text { C } \\
\text { D } \\
\text { E }\end{array}$ & $\begin{array}{l}0.069 \pm 0.013 \\
0.061 \pm 0.001 \\
0.056 \pm 0.004 \\
0.056 \pm 0.003 \\
0.022 \pm 0.001\end{array}$ \\
\hline 31 & 55.9 & 9435 & $\begin{array}{l}\text { A } \\
\text { B } \\
\text { C } \\
\text { D } \\
\text { E }\end{array}$ & $\begin{array}{l}0.054 \pm 0.001 \\
0.059 \pm 0.001 \\
0.054 \pm 0.007 \\
0.056 \pm 0.004 \\
0.053 \pm 0.007\end{array}$ \\
\hline 32 & 57.5 & 9434 & $\begin{array}{l}\text { A } \\
\text { B } \\
\text { C } \\
\text { D } \\
\text { E }\end{array}$ & $\begin{array}{l}0.056 \pm 0.003 \\
0.058 \pm 0.007 \\
0.056 \pm 0.003 \\
0.071 \pm 0.001 \\
0.036 \pm 0.009\end{array}$ \\
\hline 33 & 59.5 & 10085 & $\begin{array}{l}\text { A } \\
\text { B } \\
\text { C }\end{array}$ & $\begin{array}{l}0.071 \pm 0.001 \\
0.058 \pm 0.003 \\
0.062 \pm 0.002\end{array}$ \\
\hline 34 & 61.8 & 10086 & $\begin{array}{l}\text { A } \\
\text { B } \\
\text { C }\end{array}$ & $\begin{array}{l}0.218 \pm 0.004 \\
0.056 \pm 0.001 \\
0.059 \pm 0.001\end{array}$ \\
\hline 35 & 63.2 & 10087 & $\begin{array}{l}\text { A } \\
\text { B } \\
\text { C } \\
\text { D }\end{array}$ & $\begin{array}{l}0.073 \pm 0.003 \\
0.134 \pm 0.006 \\
0.067 \pm 0.003 \\
0.091 \pm 0.003\end{array}$ \\
\hline 36 & 65.7 & 9172 & $\begin{array}{l}\text { A } \\
\text { B } \\
\text { C } \\
\text { D } \\
\text { E } \\
\text { F } \\
\text { G } \\
\mathrm{H}\end{array}$ & $\begin{array}{l}0.066 \pm 0.002 \\
0.132 \pm 0.005 \\
0.054 \pm 0.008 \\
0.063 \pm 0.004 \\
0.156 \pm 0.003 \\
0.143 \pm 0.001 \\
0.064 \pm 0.001 \\
0.144 \pm 0.001\end{array}$ \\
\hline 37 & 66.8 & 9433 & A & $0.146 \pm 0.007$ \\
\hline 38 & 70.0 & 10088 & $\begin{array}{l}\text { A } \\
\text { B }\end{array}$ & $\begin{array}{l}0.152 \pm 0.007 \\
0.037 \pm 0.006\end{array}$ \\
\hline 39 & 71.6 & 9171 & A & $0.031 \pm 0.001$ \\
\hline 41 & 77.4 & 9170 & A & $0.054 \pm 0.009$ \\
\hline 42 & 80.1 & 9432 & A & $0.067 \pm 0.001$ \\
\hline 62 & 127.7 & 9431 & A & $0.064 \pm 0.002$ \\
\hline
\end{tabular}

${ }^{\text {a }}$ INSTAAR Amino Acid Laboratory code.

${ }^{\mathrm{b}}$ Unique AAL identifier.

Alectura eggshells provides a means of assessing the age of the specimens comprising this group of $A / I$ values. This approach provides an opportunity to assess the ability of isoleucine epimerisation in avian eggshell to yield numeric geochronological control and is an inexpensive alternative to radiocarbon dating. There are two radiocarbon-dated eggshells whose A/I values could be used to calibrate the epimerisation rate (i.e., OZF619 and OZF620). However, one of these (OZF619) is 

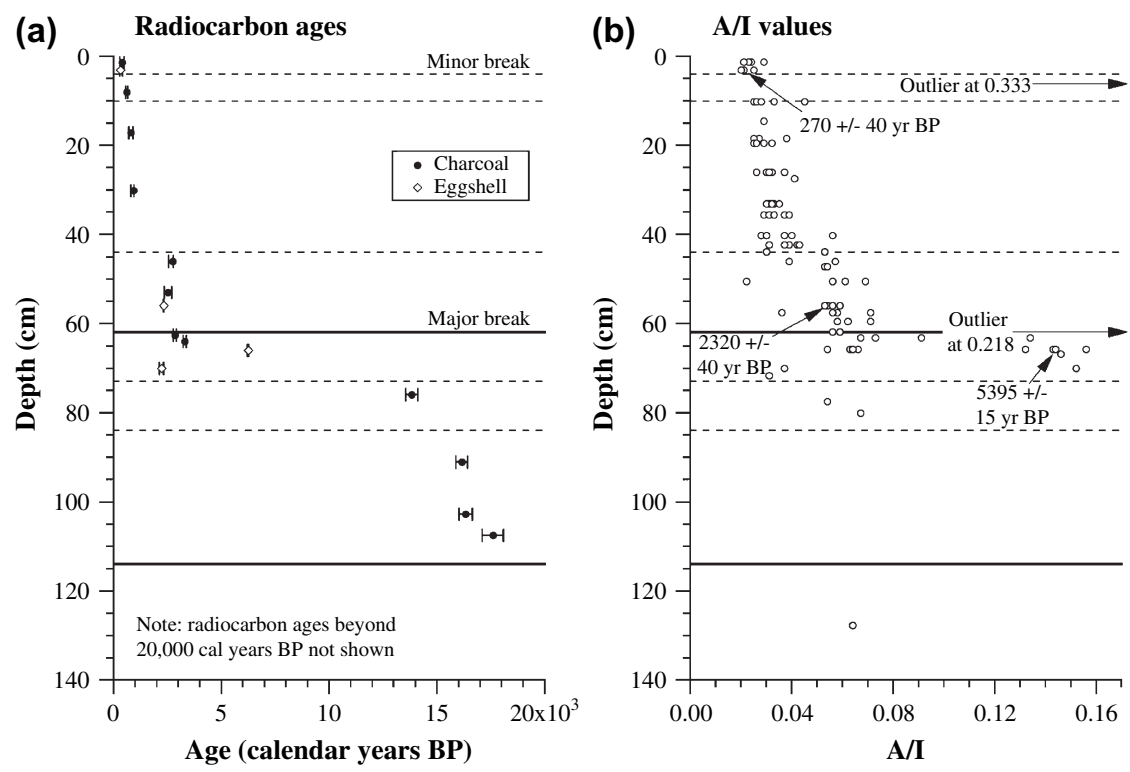

Fig. 5. Hay Cave (a) radiocarbon ages and (b) Alectura eggshell A/I values plotted with respect to depth in the sequence. The approximate locations of stratigraphic breaks are indicated. Charcoal radiocarbon ages are those of David and Lourandos (unpublished) and reported by Rowe et al. (2001).

unsuitable because the $A / I$ it exhibits is indistinguishable from that of modern eggshell: this is most likely due to the combined effects of analytical uncertainty and the slow rate of isoleucine epimerisation in Alectura eggshell. The other radiocarbon-dated eggshell has an in situ rate constant of $k_{1}=1.37 \times 10^{-5}$ year $^{-1}$, calculated by inputting the calendar age (plus 50 years) and $A / I$ of this specimen into the integrated rate equation:

$\ln (1+A / I) /\left(1-K^{\prime} A / I\right)=t k_{1}\left(1+K^{\prime}\right)+c$

where $K^{\prime}$ is the reciprocal of the equilibrium $A / I=1 /$ $1.30=0.77, t$ is the time measured in years, and $c$ is a constant obtained by solving the left-hand side of the equation using the $A / I$ of a modern specimen (i.e., $t=0$ ). Solving the integrated

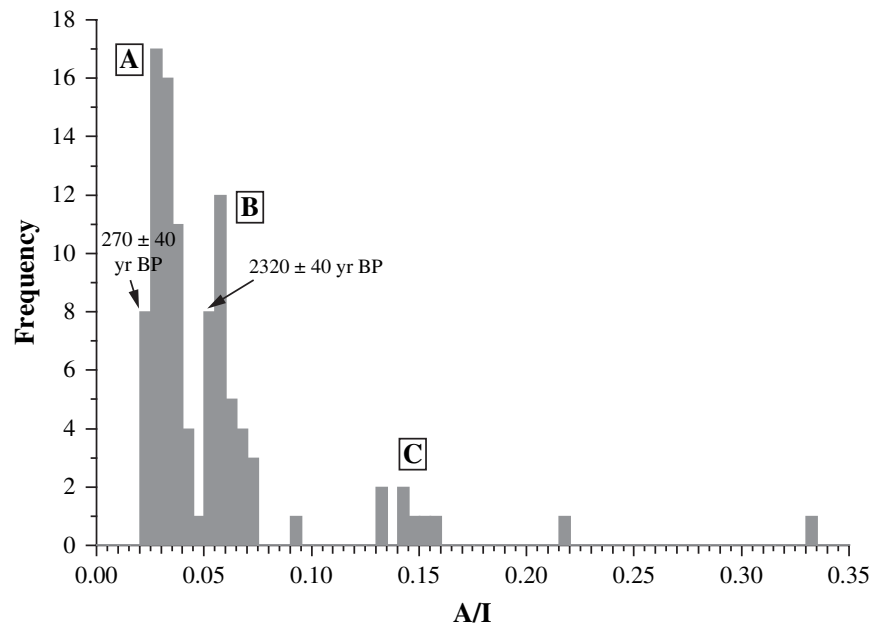

Fig. 6. Histogram of Hay Cave Alectura eggshell A/I values. Radiocarbon ages paired with $A / I$ values are indicated. Three clusters (A, B and C) of $A / I$ values are identified. rate equation for the mean $A / I$ of cluster $C$ yields an age estimate centred on 8870 calendar years. This mean value, $A /$ $I=0.144$, falls within the range that isoleucine epimerisation in Alectura eggshells was observed to obey first-order kinetics at high temperatures (up to approximately $A / I=0.6$, Clarke, 2005), supporting the use of the integrated rate equation for age estimation.

Assessing the uncertainty associated with the age estimate for cluster $\mathrm{C}$ is difficult given the single acceptable calibration point for the reaction rate and poor understanding of the thermal history of the site. An attempt to quantify this uncertainty is presented in Table 5. To combine the uncertainty arising from the amino acid and radiocarbon measurements, these sources of error were algebraically propagated through the integrated rate equation using methods described by Taylor (1982). By this method, the age of cluster $\mathrm{C}$ has an associated uncertainty of approximately $1 \%$, but this is based on the assumption that the eggshells of unknown age have experienced a thermal history equivalent to that experienced by the calibration sample. Assuming that the thermal histories of the calibration sample and eggshells of unknown age agree to within $\pm 0.5^{\circ} \mathrm{C}$, and using an $E_{\mathrm{a}}$ of $30.8 \mathrm{kcal} \mathrm{mol}^{-1}$ as a representative value for modelling the temperature sensitivity of the rate of isoleucine epimerisation in Alectura eggshells (Clarke, 2005), the uncertainty in the age estimate increases to $+9.1,-8.4 \%$ (Table 5). For the eggshells with $A / I$ values in cluster $\mathrm{C}$, this corresponds to an age and asymmetric error term of $8870+810,-740$ years. Because the uncertainty associated with this age increases from about $1 \%$ to $9 \%$ when the $\pm 0.5^{\circ} \mathrm{C}$ temperature uncertainty is incorporated (Table 5), and because the size of the uncertainty associated with temperature is an indeterminate source of error, the age calculation is necessarily considered an estimate. This error range seems to be a reasonable approximation, however, because the range of $A / I$ values in cluster $C$ is similar to those observed in clusters 
Table 5

Calculations used to estimate the age of Alectura eggshells from Hay Cave based on isoleucine epimerisation

\begin{tabular}{llll}
\hline Calculation & $t \pm \mathrm{SD}($ years $)(\%$ error $)$ & $A / I \pm$ SD $(\%$ error $)$ & $k_{1}\left(\right.$ years $\left.{ }^{-1}\right)(\%$ error $)$ \\
\hline $\begin{array}{l}\text { In situ calibration of the rate of } \\
\quad \text { isoleucine epimerisation }\end{array}$ & $2390 \pm 40(1.7)^{\mathrm{a}}$ & $0.054 \pm 0.007(13.0)$ & $1.37 \times 10^{-5} \pm 1.64 \times 10^{-7}(1.2)^{\mathrm{b}}$ \\
$\begin{array}{l}\text { Calculating the age and associated random } \\
\quad \text { errors of eggshells with cluster C } \mathrm{A} / \mathrm{I} \text { values }\end{array}$ & $8865 \pm 80(0.9)^{\mathrm{b}}$ & $0.144 \pm 0.013(9.0)^{\mathrm{c}}$ & \\
$\begin{array}{l}\text { Estimating the uncertainty } \\
\quad \text { of a } 0.5^{\circ} \mathrm{C} \text { error in temperature }\end{array}$ & & $(+9.1,-8.4)^{\mathrm{d}}$ \\
$\quad \begin{array}{l}\text { Rounding after accounting for } \\
\text { temperature uncertainty }\end{array}$ & $8870+810,-740(+9.1,-8.4)^{\mathrm{c}}$ & & \\
\hline
\end{tabular}

${ }^{\text {a }}$ Fifty years was added to equate the duration of epimerisation with the duration of radiocarbon decay, and the analytical uncertainty ( $\left.1 \sigma\right)$ was used to estimate the standard deviation.

${ }^{\mathrm{b}}$ Error term estimated by algebraically propagating errors through the integrated rate equation.

${ }^{c}$ Error term estimated from the square root of the sum of errors squared.

${ }^{\mathrm{d}}$ Error term estimated from the slope of the Arrhenius equation, $\ln \left(k_{1}\right)=-E_{\mathrm{a}} / R T$, using the $E_{\mathrm{a}}$ for isoleucine epimerisation in Alectura eggshell calculated by Clarke (2005), $30.8 \mathrm{kcal} \mathrm{mol}^{-1}$, where $R$ is the gas constant $\left(=0.0019872 \mathrm{kcal} \mathrm{mol}^{-1}\right)$ and $T$ is temperature in Kelvin.

$\mathrm{A}$ and $\mathrm{B}$, and each of these younger clusters span about 1000 years (Figs. 5 and 6 ).

The age estimate for cluster $\mathrm{C}$ is in accord with the radiocarbon chronology for the sequence (i.e., it does not suggest stratigraphic inversion or mixing) and is in accord with the possibility that the Hay Cave sequence includes sediments deposited during the Early Holocene (Rowe et al., 2001). However, to assess the isoleucine epimerisation age estimate an additional Alectura eggshell from cluster C (AAL9172H) was submitted for radiocarbon dating. This eggshell has a calibrated radiocarbon age of approximately $6200 \mathrm{cal}$ years BP (NSRL-14448, Table 1). This is about 2700 years or $30 \%$ less than the isoleucine epimerisation age estimate. It therefore appears that the calculated in situ rate constant is too low for cluster $\mathrm{C}$ eggshells. The reason for this is not clear but could be explained by an effective diagenetic temperature for the cluster $\mathrm{C}$ eggshells $2{ }^{\circ} \mathrm{C}$ warmer than the 2400 year old calibration sample, perhaps resulting from $c a .3000$ years of shallow burial prior to the deposition of sediments associated with cluster B. It is concluded that the cluster C eggshells represent occupation of Hay Cave in the Mid Holocene, and, in accord with the findings of previous researchers (Miller and Hare, 1980; Wehmiller and Miller, 2000), uncertainty associated with use of isoleucine epimerisation to estimate numeric ages is inherently greater than the use of $A / I$ values to infer relative ages, especially when extrapolating outside the range of calibration points.

Less than 5\% of the Alectura eggshells subjected to amino acid analysis yielded high $A / I$ values due to an anomalously high effective diagenetic temperature produced by exposure to campfire heating events. This increases confidence in the use of $A / I$ to estimate sample age, and is in sharp contrast to the greater abundance of Casuarius eggshells with anomalously high $A / I$ values in the archaeological sites of the Ayamaru Plateau and Aru Islands. The results reported by Clarke and Miller (2005) on Casuarius eggshells from the Aru Islands are significant because they reiterate the trends seen in the Ayamaru Plateau $A / I$ values. From good correlations between relatively low $A / I$ values (presumably 'unburnt') and radiocarbon ages, the Aru Islands results also indicate that Casuarius eggshell amino acids can provide geochronological information, but confidence in $A / I$ as an independent form of age control was undermined by the large range in values observed in eggshells from similar depths (Clarke and Miller, 2005).

The low incidence of 'burnt' megapode eggshells may reflect the methods used to prepare Alectura eggs for consumption. Exposure to high temperatures expands the contents of eggs, inducing cracks and risking the loss of their nutritious contents. Several methods of cooking megapode eggs are known and some of these minimise the exposure of the egg to high temperatures. For example, Lumholtz, writing in 1889, observed Australian Aborigines pierce fresh megapode eggs, place them in hot ashes and retrieve the contents by dipping a make-shift brush through the hole, a cooking method that would expose only one half of the eggshell to high temperatures (Lumholtz, 1980). Similarly, Pernetta (1989) observed the cooking of megapode eggs in ashes but also by emptying their contents into bamboo tubes or wrapping them in banana leaves to be cooked, methods that do not necessitate the exposure of eggshell to high temperatures. Casuarius eggs, on the other hand, may not have been treated so carefully as their robust eggshell is more likely to resist cracking. The Alectura eggshell amino acid results provide further evidence that anomalous thermal histories in archaeological sites can produce elevated $A / I$ values. However, the low incidence of unusually high $A / I$ values at Hay Cave indicates that this is not necessarily a disabling problem when seeking to refine site chronology with amino acid biogeochemistry.

\section{Conclusions}

As observed in Struthio eggshells and other sample types in which the extent of amino acid racemisation or isoleucine epimerisation has been investigated to generate geochronological control for archaeological sequences, interpretation of the $A / I$ values of Casuarius and megapode eggshells from Ayamaru Plateau archaeological sites in terms of sample age is complicated by their exposure to the high temperatures associated with campfire heating events. Nevertheless, the tendency towards relatively low $A / I$ values in Kria Cave eggshells 
compared to values observed in Toé Cave specimens is in accord with radiocarbon ages indicating that the former sequence was deposited during the Holocene, and that the latter site has been accumulating since the Pleistocene. The most coherent geochronological information was obtained from eggshells with low $A / I$ values relative to those exhibited by eggshells excavated from similar depths: amongst such samples Casuarius eggshells with values of $A / I<0.2$ were observed at both caves amongst sediments deposited during the Holocene, and results where $0.3<A / I<0.4$ were observed amongst Pleistocene Toé Cave eggshells.

Examination of the extent of isoleucine epimerisation in Alectura eggshells has helped determine the timing of the deposition of the Hay Cave archaeological site. The $A / I$ values grouped into two Late Holocene clusters, one dated from $c a$. 2000 to 3500 cal years BP, the other from $c a$. 1000 cal years $\mathrm{BP}$ to the present, and another cluster upon which a Mid Holocene radiocarbon age was obtained. Although an attempt to estimate a numeric age from $A / I$ values was problematic the eggshell amino acid results are nonetheless important for defining the temporal nature of the Holocene archaeological record at Hay Cave.

\section{Acknowledgements}

This work benefited from sorting of the Hay Cave archaeological materials by Angela Holden (University of Queensland). Charles P. Hart is thanked for maintaining the liquid chromatograph used for amino acid analyses. Eggshell radiocarbon ages were supported by AINSE grants 01/107 and 02/091. SJC received financial assistance for this research from an Australian Postgraduate Award. This work has benefited from the comments of two anonymous reviewers for which they are thanked.

\section{References}

Aplin, K.P. (1998). Vertebrate zoogeography of the Bird's Head of Irian Jaya, Indonesia. Perspectives on the Bird's Head of Irian Jaya, Indonesia. Proceedings of the Conference Leiden, 13-17 October 1997, Leiden, pp. 803-890.

Bird, M.I., Fifield, L.K., Santos, G.M., Beaumont, P.B., Zhou, Y., di Tada, M.L., Hausladen, P.A., 2003. Radiocarbon dating from 40 to $60 \mathrm{ka} \mathrm{BP}$ at Border Cave, South Africa. Quaternary Science Reviews 22, 943-947.

Bowman, D.M.J.S., Panton, W.J., Head, J., 1999. Abandoned Orange-footed Scrubfowl (Megapodius reinwardt) nests and coastal rainforest boundary dynamics during the late Holocene in monsoonal Australia. Quaternary International 59, 27-38.

Brooks, A.S., Hare, P.E., Kokis, J.E., Miller, G.H., Ernst, R.D., Wendorf, F., 1990. Dating Pleistocene archaeological sites by protein diagenesis in ostrich eggshell. Science 248, 60-64.

Brooks, A.S., Smith, C.C., 1987. Ishango revisited: new age determinations and cultural interpretations. The African Archaeological Review 5, 65-78.

Clarke, S.J., 2005. Isoleucine epimerisation and stable isotope ratio studies of cassowary, megapode and Aepyornis eggshells: biogeochemical and palaeoenvironmental implications. Unpublished $\mathrm{PhD}$ thesis, University of Wollongong, Australia. Available online at http://www.library.uow.edu.au/ theses/.

Clarke, S.J., Miller, G.H., 2005. Isoleucine epimerization in Casuarius eggshells from Aru Islands archaeological sites, Liang Lemdubu and Nabulei
Lisa. In: O'Connor, S., Spriggs, M., Veth, P. (Eds.), The Archaeology of the Aru Islands, Eastern Indonesia. Terra Australis, Vol. 22. Pandanus Books, Research School of Pacific and Asian Studies, The Australian National University, pp. 295-306.

David, B., Chant, D., 1995. Rock art and regionalisation in north Queensland prehistory. Memoirs of the Queensland Museum 37, 357-528.

Goodfriend, G.A., Ellis, G.L., 2000. Stable carbon isotope record of middle to late Holocene climate changes from land snail shells at Hinds Cave, Texas. Quaternary International 67, 47-60.

Grün, R., Beaumont, P., 2001. Border Cave revisited: a revised ESR chronology. Journal of Human Evolution 40, 467-482.

Hare, P.E., Goodfriend, G.A., Brooks, A.S., Kokis, J.E., von Endt, D.W., 1993. Chemical clocks and thermometers: diagenetic reactions of amino acids in fossils. Carnegie Institution of Washington Year Book 92, 80-85.

Henry, D.O., Miller, G.H., 1992. The implications of amino acid racemization dates of Levantine Mousterian deposits in southern Jordan. Paléorient 18, $45-52$.

Holden, A., 1999. A technological analysis of the lithic assemblage from Hay Cave, S.E. Cape York Peninsula: considering diachronic variations in patterns of intensity of site use. Unpublished Honours thesis, University of Queensland.

Hughen, K., Lehman, S., Southon, J., Overpeck, J., Marchal, O., Herring, C., Turnbull, J., 2004. ${ }^{14} \mathrm{C}$ activity and global carbon cycle changes over the past 50,000 years. Science 303, 202-207.

Jelsma, J., 1998. Room with a view. An excavation in Toé cave, Ayamaru district, Bird's Head, Irian Jaya. In: Bartstra, G.-J. (Ed.), Bird's Head Approaches: Irian Jaya Studies - A Programme for Interdisciplinary Research. Modern Quaternary Research in Southeast Asia, vol. 15. A.A. Balkema, Rotterdam, pp. 41-65.

Johnson, B.J., Miller, G.H., Fogel, M.L., Beaumont, P.B., 1997. The determination of late Quaternary paleoenvironments at Equus Cave, South Africa, using stable isotopes and amino acid racemization in ostrich eggshell. Palaeogeography, Palaeoclimatology, Palaeoecology 136, 121-137.

Johnson, B.J., Miller, G.H., Fogel, M.L., Magee, J.W., Gagan, M.K., Chivas, A.R., 1999. 65,000 years of vegetation change in central Australia and the Australian summer monsoon. Science 284, 1150-1152.

Jones, D.N., Dekker, R.W.R.J., Roselaar, C.S., 1995. The Megapodes: Megapodiidae. Bird Families of the World, 3. Oxford University Press, Oxford.

Kokis, J.E., Hare, P.E., Brooks, A.S., 1998. Stratigraphic analysis of White Paintings Shelter, Botswana utilizing isoleucine epimerization in ratite eggshell. Amino Acids 15, 280-281.

Lumholtz, C.S., 1980. Among Cannibals: Account of Four Years Travels in Australia, and of Camp Life with the Aborigines of Queensland. Australian National University Press, Canberra.

Magee, J.W., Miller, G.H., 1998. Lake Eyre palaeohydrology from 60 ka to the present: beach ridges and glacial maximum aridity. Palaeogeography, Palaeoclimatology, Palaeoecology 144, 307-329.

Miller, G.H., Beaumont, P.B., Deacon, H.J., Brooks, A.S., Hare, P.E., Jull, A.J.T., 1999a. Earliest modern humans in southern Africa dated by isoleucine epimerization in ostrich eggshell. Quaternary Science Reviews $18,1537-1548$.

Miller, G.H., Beaumont, P.B., Jull, A.J.T., Johnson, B., 1992. Pleistocene geochronology and palaeothermometry from protein diagenesis in ostrich eggshells: implications for the evolution of modern humans. Philosophical Transactions of the Royal Society of London B 337, 149-157.

Miller, G.H., Brigham-Grette, J., 1989. Amino acid geochronology: resolution and precision in carbonate fossils. Quaternary International 1, 111-128.

Miller, G.H., Hare, P.E., 1980. Amino acid chronology: integrity of the carbonate matrix and potential of molluscan fossils. In: Hare, P.E., Hoering, T.C., King Jr. K. (Eds.), Biogeochemistry of Amino Acids. John Wiley and Sons, New York, pp. 415-443.

Miller, G.H., Magee, J.W., Johnson, B.J., Fogel, M.L., Spooner, N.A., McCulloch, M.T., Ayliffe, L.K., 1999b. Pleistocene extinction of Genyornis newtoni: human impact on Australian megafauna. Science 283, 205-208.

Miller, G.H., Wendorf, F., Ernst, R.D., Schild, R., Close, A.E., Friedman, I., Schwarcz, H.P., 1991. Dating lacustrine episodes in the eastern Sahara by the epimerization of isoleucine in ostrich eggshells. Palaeogeography, Palaeoclimatology, Palaeoecology 84, 175-189. 
Murray-Wallace, C.V., Colley, S.M., 1997. Amino acid racemisation and radiocarbon dating of a contact period midden, Greenglade rockshelter, New South Wales. Archaeology in Oceania 32, 163-169.

Pasveer, J.M., 1998. Kria cave: an 8000-year occupation sequence from the Bird's head of Irian Jaya. In: Bartstra, G.-J. (Ed.), Bird's Head Approaches: Irian Jaya Studies - A Programme for Interdisciplinary Research. Modern Quaternary Research in Southeast Asia, Vol. 15. A.A. Balkema, Rotterdam, pp. 67-89.

Pasveer, J.M., 2004. The Djief Hunters. 26,000 Years of Rainforest Exploitation on the Bird's Head of Papua, Indonesia. In: Modern Quaternary Research in Southeast Asia, Vol. 17. A.A. Balkema Publishers, Lisse.

Pasveer, J.M., Aplin, K.P., (1998). Late Pleistocene to modern vertebrate faunal succession and environmental change in lowland New Guinea: evidence from the Bird's Head of Irian Jaya, Indonesia. Perspectives on the Bird's Head of Irian Jaya, Indonesia: Proceedings of the Conference Leiden, 13-17 October 1997, Leiden, pp. 891-930.

Pasveer, J.M., Clarke, S.J., Miller, G.H., 2002. Late Pleistocene occupation of inland rainforest, Bird's Head, Papua. Archaeology in Oceania 37, 92-95.

Pernetta, J.C., 1989. Analysis of faunal remains from the archaeological sites. In: Gorecki, P.P., Gillieson, D.S. (Eds.), A Crack in the Spine: Prehistory and Ecology of the Jimi-Yuat Valley, Papua New Guinea. James Cook University of North Queensland, Townsville, pp. 191-208.
Rich, P.V., Plane, M., Schroeder, N., 1988. A pygmy cassowary (Casuarius lydekkeri) from late Pleistocene bog deposits at Pureni, Papua New Guinea. BMR Journal of Australian Geology and Geophysics 10, 377-389.

Rowe, C., Stanisic, J., David, B., Lourandos, H., 2001. The helicinid land snail Pleuropoma extincta (Odhner 1917) as an environmental indicator in archaeology. Memoirs of the Queensland Museum 46, 741-770.

Stocker, G.C., 1971. The age of charcoal from old jungle fowl nests and vegetation change on Melville Island. Search 2, 28-30.

Stuiver, M., Reimer, P.J., 1993. Extended ${ }^{14} \mathrm{C}$ database and revised CALIB radiocarbon calibration program. Radiocarbon 35, 215-230.

Taylor, J.R., 1982. An Introduction to Error Analysis: The Study of Uncertainties in Physical Measurements. University Science Books, Mill Valley.

Wehmiller, J.F., Miller, G.H., 2000. Aminostratigraphic dating methods in Quaternary geology. In: Sowers, J.M., Lettis, W.R. (Eds.), Quaternary Geochronology: Methods and Applications. American Geophysical Union Books Board, Washington, DC, pp. 187-222.

Wehmiller, J.F., York, L.L., Bart, M.L., 1995. Amino acid racemization geochronology of reworked Quaternary mollusks on U.S. Atlantic coast beaches: implications for chronostratigraphy, taphonomy, and coastal sediment transport. Marine Geology 124, 303-337.

Williams, K.M., Smith, G.G., 1977. A critical evaluation of the application of amino acid racemization to geochronology and geothermometry. Origins of Life 8, 91-144. 